\title{
SHAKESPEARE CHECKS INTO THE DIGITAL WORLD: REWRITING HIS PLAYS USING EMOJIS
}

\author{
Marcia Amaral Peixoto Martins ${ }^{1}$ \\ Ofélia da Conceição Machado Sagres ${ }^{1}$ \\ 1Pontificia Universidade Católica, Rio de Janeiro, Rio de Janeiro, Brasil
}

\begin{abstract}
This study analyzes the $O M G$ Shakespeare series, which aims at bringing Shakespeare's plays to young audiences using digital language. The series features rewritings of Shakespeare's plays into WhatsApp-message format. There are four titles available: srsly Hamlet, Macbeth \#killingit, YOLO Juliet and A Midsummer Night \#nofilter. The analysis seeks to determine: i) the general concept of the series; ii) the main strategies used in the intermedial adaptation of the plays and iii) the relationships between verbal and visual languages in the texts. The theoretical framework relies on Irina Rajewisky's (2010) and Werner Wolf's (1999) concepts of intermediality, Charles Peirce's (1998) theory of signs, Lars Elleström's $(2010,2013)$ conceptual framework on modality and media and on Linda Hutcheon's (2013) concepts of adaptation.
\end{abstract}

Keywords: Shakespeare; Adaptation; Intermediality; Visual Language

\section{SHAKESPEARE VISITA O MUNDO VIRTUAL: O USO DE EMOJIS EM REESCRITAS DE SUAS PEÇAS}

Resumo: Este estudo faz uma análise da série $O M G$ Shakespeare, cujo objetivo é levar para o público jovem, através do uso da linguagem digital, as peças de William Shakespeare. A série apresenta reescritas das peças de Shakespeare no formato de mensagens de WhatsApp. Os quatro títulos disponíveis são: srsly Hamlet, Macbeth \#killingit, YOLO Juliet and A Midsummer Night \#nofilter. Busca-se determinar: i) o conceito geral da série; ii) as principais estratégias empregadas na adaptação intermidiática das peças e iii) as relações entre as linguagens verbal e não verbal nos textos. $\mathrm{O}$ arcabouço teórico desta análise baseia-se nos conceitos de inter- 
midialidade de Irina Rajewisky (2010) e Werner Wolf (1999), na teoria dos signos de Charles Peirce (1998), nas concepções de modalidade e de mídia de Lars Elleström $(2010,2013)$ e nos conceitos de adaptação de Linda Hutcheon (2013).

Palavras-Chave: Shakespeare; Adaptação; Intermidialidade; Linguagem Visual

The purpose of this paper is to discuss four intermedialconfiguration rewritings of Shakespeare's plays that make up the OMG Shakespeare series, published by Penguin Random House for Young Readers. William Shakespeare is unquestionably part of the western world literary canons, and perhaps of some of the Eastern world ones. Harold Bloom states that his "powers of assimilation and of contamination are unique" (Bloom 13). One may even say that Shakespeare "is already not only modern but postmodern: a simulacrum, a replicant, a montage, a bricolage. A collection of found objects, repurposed as art" (Garber xvii). When one talks about different "Shakespeares" in contemporaneity, it's also important to call attention to the fact that "in our digital age many works of art, cultural artifacts, literary texts and other cultural configurations either combine and juxtapose different media, genres and styles or refer to other media" (Rippl 1).

The $O M G$ series features adaptations of four plays so far: srsly Hamlet and Macbeth \#killing it, by Courtney Carbone, and YOLO Juliet and A Midsummer Night \#nofilter, by Brett Wright. Taking advantage of the intermediality trend, the goal of its authors and editors is to bring Shakespeare's works to the youth universe through the use of texts in WhatsApp-message format. WhatsApp messages use a creative combination of emojis, symbols and verbal text. The term "emoji" "comes from the Japanese character (絵, "picture") + moji (文字, “character")." It was “introduced by Shigetaka Kurita in Japan in the late 1990s (Alshenqeeti 57) and is defined as "any of various small images, symbols, or icons used in text fields in electronic communication (as in text messages, e-mail, and social media) to express the emotional attitude of the writer, convey information succinctly, communicate a message playfully 
without using words" ("Emoji") (Alshenqeeti 56). The selection of the face with tears of joy emoji as the "Word of Year 2015" by the English Oxford Living Dictionary reflects the emojis' importance in communication. The dictionary entry states that it was "the word that best reflected the ethos, mood, and preoccupations of 2015."

According to Penguin Random House website for teachers and librarians (RHTeachersLibrarians.com, 2015), these companions, as they are called by the publishing house, "are a fresh alternative to SparkNotes and can be used alongside the original text to hook your students and help them see that Shakespeare's masterpieces are still relevant". Although the original core audience of the adaptations is young native speakers of English, it is possible to discuss the potential use of the books in EFL/ESL teaching contexts. In this paper, we analyze intermedial and multimodal aspects in the OMG Shakespeare series and the possible contributions to each of the two groups.

To address the interaction between the four adaptations and the digital format, our analysis discusses two categories of adaptation (media adaptation and narrative adaptation). The discussion of (inter)mediality and modality is based on the conceptual frames of Irina Rajewisky, Werner Wolf, Charles Peirce and Lars Elleström. In spite of the several intermediality conceptions connected to different approaches to the area, one can say that intermediality is, in a broad sense, "a result of constructed media borders being trespassed" (Elleström, "The Modalities" 27). In a narrower sense, this concept can

be defined as a particular relation [...] between conventionally distinct media of expression or communication; this relation consists in a verifiable, or at least convincingly identifiable, direct or indirect participation of two or more media in the signification of a human artefact" (Wolf 37).

In order to classify the adaptations of Shakespeare's plays, this essay makes use of Irina Rajewisky's literary subcategories 
of intermediality. Rajewisky acknowledges that there are not pure media but believes that it is important to establish some borders and specificities. She classifies the intermedial works according to their concrete medial configurations, their intermedial qualities and their way of crossing media borders:

1. Intermediality in the narrower sense of medial transposition (Medien-wechsel), also referred to as medial transformation, as for example, film adaptations of literary texts $[\ldots]$.

2. Intermediality in the narrower sense of media combination (Medien-kombination), which includes phenomena such as opera, film, theater $[\ldots]$.

3. Intermediality in the narrower sense of intermedial references (intermediale Bezüge), for example, references in a literary text to a specific film, film genre or filmi qua medium [...]. (Rajewisky 55).

Lars Elleström also considers adaptation a specific kind of media transformation (Elleström, "Adaptation and Intermediality" 511). In this regard, as adaptations of Shakespeare's plays, Courtney Carbone's and Brett Wright's works may be considered "medial transpositions", since they are narrative texts of plays (from the theater to the book). However, unlike Elleström, who states that the "'pointing' to a medium from the viewpoint of another medium" (Elleström, "Adaptation and Intermediality" 511) is not adaptation, our analysis defines the four rewritings as "intermedial references" and "adaptations". They are references because "only one conventionally distinct medium manifests itself in its specific materiality and mediality" (Rajewisky 58). Macbeth \#killing it, srsly Hamlet, YOLO Juliet and A Midsummer Night \#nofilter simulate WhatsApp messages but are still books, i.e., there is only one medium involved. This aspect is very important because, as Lars Elleström points out, each media product has characteristics (physical properties and cognitive processes) that 
involve possibilities and restrictions. For this reason, a technical medium (an object or body that mediates) cannot serve as a medium to another technical medium, that is, some "qualified media are actually fundamentally linked to irreplaceable technical media. Hence, technical media inevitably also play a crucial part in the forming of the characteristic aesthetic and communicative qualities of qualified media [...]" (Elleström, "The Modalities" 33). In the passage from Macbeth \#killing it below, for example, there are two hyperlinks (one of the anchors is a verbal text and the other is a button), but they do not work, since the technical medium "book" cannot interact with other books or computers.

Fig. 1: Hyperlinks in a book

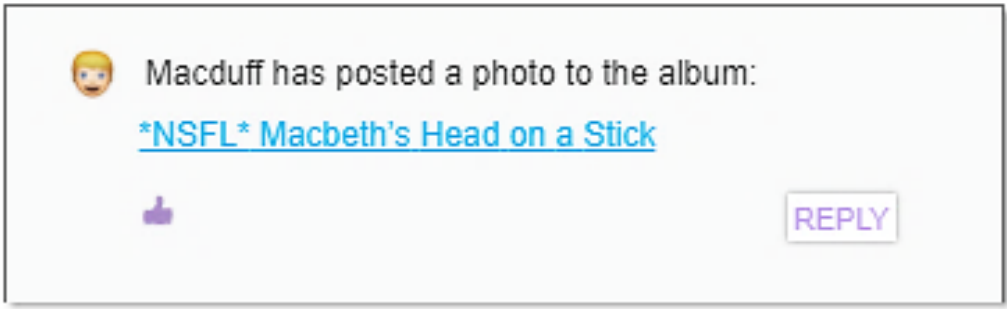

Source: (Shakespeare and Carbone (a) 79).

Intermediality studies bring out the concept of multimodality. We believe this merging of perspectives is essential in the analysis of the OMG Shakespeare series. To this end, we resort to Lars Elleström's notion that four modalities "form the specific character of every medium" (Elleström, "The Modalities" 23): three presemiotic modalities (material, sensorial and spatiotemporal) and the semiotic modality, which is derived from the pre-semiotic ones.

In relation to the OMG Shakespeare series, one may say that it involves material and spatiotemporal cross-modality, since a physical flat static material represents a digital one, which is able to change and interact. Our analysis, however, emphasizes the sensorial and semiotic modalities, seeing how it deals with visual 
signs and representation. Besides, the combinations of sensorybased and semiotic modes is one characteristic of the medium represented, that is, the digital messages.

Elleström proposes that one of Charles Peirce's trichotomy of signs related to the object, that is, "symbol" (convention), "icon" (resemblance) and "index" (contiguity) "should be seen as the three main modes of the semiotic modality" (Elleström, "The Modalities" 22). Peirce defines a sign as:

a thing which serves to convey knowledge of some other thing, which it is said to stand for or represent. This thing is called the object of the sign; the idea in the mind that the sign excites, which is a mental sign of the same object, is called an interpretant of the sign. (Peirce 13)

According to Peirce, although there are not pure signs, one may say that "icons" are, in most cases, "likenesses of their objects" (Peirce 13). "Indices" stand for their object "by virtue of a real connection with it, or because it forces the mind to attend to that object" (Peirce 14). A symbol, on the other hand, "is a representamen which fulfills its function regardless of any similarity or analogy with its object and equally regardless of way factual connection therewith, but solely and simply because it will be interpreted to be a representamen" (Peirce 163).

In the rewritings, there is, in our view, a predominance of the symbolic function on account of the verbal language. In relation to the use of pictographs, so characteristic of digital messages, iconic-sign functions are more common. In the passage from $A$ Midsummer Night \#no filter below, one can realize the direct relationship between the nonverbal representamens (emojis) and the objects. 
Fig. 2: Iconic nature of emojis

\section{BACK}

\section{OBERON}

Great-she's asleep. ${ }^{z} z^{z}$ Now to squeeze this 98 into her

- . When you wake up, you'll love whatever you see first.

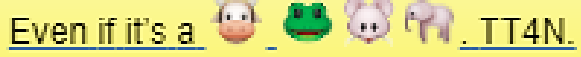

Source: (Shakespeare and Wright (a) 29).

Elleström defines iconicity as gradable "mimetic relations between form and meaning (Elleström, "Iconicity" 73), which can be strong or weak. Strong iconicity is based on immediate resemblance (a small distance between representamen and object)" and it is "determined by sensory qualities of the representamen and cognitively less complex" (Elleström, "Spatiotemporal aspects" 105). Weak iconicity, on the other hand, requires more complex cognitive operations to understand the representamen since it is based on weak sensuous resemblance (Elleström, "Spatiotemporal aspects" 105). The use of images in the OMG Series (strong iconicity) may be related to the target audience and to the pedagogical purpose of the adaptations. One may say, therefore, that the use of emojis ("picture characters") and photos aim at the simplification of the text, the facilitation of its comprehension and the evoking of the readers' interest. The passage from srsly Hamlet below, in which there is only one nonverbal symbol, clearly shows the strong iconic nature of the majority of the nonverbal visual signs: 
Fig. 3: Icons and symbols

Ophelia

\section{i have $\$$ your words in my and you alone have the but it goes both ways. you better stay out of trouble in 11 l!}

Source: (Shakespeare and Carbone (b) 18).

Even the use of some symbols may be based on the similarity to the object. In "IT'S SO NICE TO MEET YOU!!!! X O" (Shakespeare and Carbone (b) 65), the symbol " $\mathrm{X}$ " may suggest two people embracing and the symbol "O" seems to be an open mouth. This connection to the object, however, as Elleström draws attention to, is weaker and demands a certain context and "complex acts of interpretation" (Elleström, "Spatiotemporal aspects" 107).

This emphasis on simplicity is reinforced by the fact that, in order to avoid misunderstandings, lists of some ambiguous symbols (emotions) and acronyms are provided at the end of the books. Some emojis are also accompanied by the related English word in the written texts. When dealing with universal symbols, on the other hand, the books do not provide explanations: 
Fig. 4: The relationship between emojis and verbal signs in Macbeth \#killingit

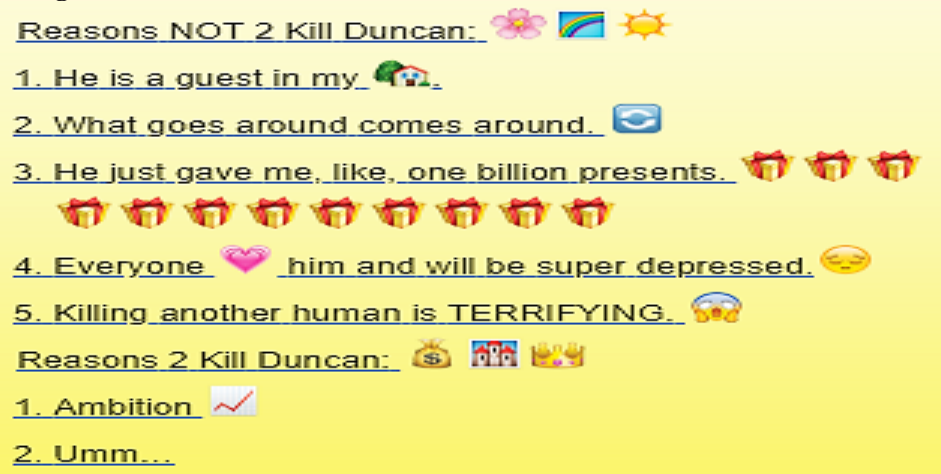

Source: (Shakespeare and Carbone (a) 19).

One can see above that "presents" and the wrapped present emoji, for instance, convey the same meaning. The refresh or rotate emoji (anticlockwise downwards and upwards open circle arrow emoji) is another example of the use of double representamen.

Elleström also stresses that iconicity is "part of the sociomaterial world; constantly changing and always filtered through and created by the human mind" (Elleström, "The Modalities" 86). One may say, therefore, that the relationship between the object, the representamen, and the interpretant depends on the context, is not universal and is gradable. One example can be seen in the signification attached to the honeybee emoji. In this passage from A Midsummer Night \#nofilter, we have an "image", which is one extreme in the scale of iconicity. The similarity is strong, i.e., the bumblebee image refers to the animal in a mono-modal relation and it is easy to perceive similarities and differences between the object and the sign: 
Fig. 5: The bee emoji as an animal

Bottom

\section{Greatl Can you go kill a oy. for me and bring back the ? Thx!}

Source: (Shakespeare and Wright (a) 65).

In the passage from srsly Hamlet below there is a crossing of borders, that is, the bumblebee emoji is miming auditory phenomena. This phenomenon is called cross-modality and should "be understood as cross-material, cross-spatiotemporal, and cross-sensorial representation through iconicity, indexicability, or simbolicity" (Elleström, "Identifying, Cosntruing, and Bridging" 24). Cross-modal iconicity demands, according to Elleström "more active interpretation of the beholder, a suggestive context, or rather pronounced conventional sign-functions that support the iconic aspects". In terms of cross-sensorial iconicity, the honeybee pictograph may be classified as a "diagram" since it is a relational sign. This diagram is weak because it mirrors the internal relations of the object in "a more abstract form" (Elleström, "Iconicity" 82):

Fig. 6: The bee emoji as a diagram

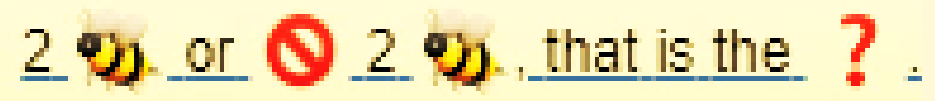

Source: (Shakespeare and Carbone (b) 42).

The same kind of classification may be applied to the symbol "2". In both cases, there are two visual-sensory signs that refer to two auditory signs. These two auditory signs (/bi:/ and /tu:/) become, then, representamens of abstract or cognitive processes. 
As claimed by Elleström, the weak diagrams and the metaphors, connected to low degrees in the continuum of iconicity, demand more complex cognitive processes and are the only categories that are able to cross modal borders. In the passage from YOLO Juliet below, the bumblebee emoji functions as a referential sign (the idea of pollination) and a metaphor. In spite of the resemblance of the spectacular format of the flower and the sting of the bee to sexual organs, it involves complex interpretation to relate these the emojis and the words "flower" and "pollinated" to sexual intercourse. That is why one may classify this passage as a cognitive-based metaphor.

Fig. 7: The bee emoji as a metaphor

\section{Mercutio}

\section{Out with it then! So how was her pink flower?}

Benvolio

Ugh. Mercutio.

Romeo

Let's just say it's been pollinated. of.

Source: (Shakespeare and Wright (b) 51).

It is interesting to point out that the idea of pollination of plants not only reinforces the importance of convention/culture in the interpretation but also is generally associated to sexual education discourses for children. This metaphorical function of the sign may, therefore, be associated with the target audience of the books.

As regards the intermedial and cross-modal nature of the series, it is possibly a resource used by the adaptors to meet the assumed 
expectations of the target audience and of educators (an educational site address, for example, is mentioned in the colophon). As Erica Hateley states, “children's literature achieves its formative function by serving two masters: education and entertainment, the latter often masking the former" (Haleley 15).

It is necessary, nevertheless, to draw attention to the fact that this multifaceted nature may be an attempt to reproduce Shakespearean theatrical space in a contemporary way. One may say that the four adaptations, taken as picture books, pay attention to the "readability" or performance of the verbal text and their "illustrations are a kind of set design for the text; as in the theater, they have an effect on the audience" (Oittinen 16). Monica MateiChesnoiu declares that the bard's plays are performed "in theatres featuring non-illusionistic scenery, Shakespeare's plays establish location through movement, language, gesture, and costume" (61). It can be said, therefore, that Shakespeare's plays and the $O M G$ series deal with virtual spaces where characters enter and exit. In the four rewritings, movement, costume and gesture are presented through visual iconic signs:

Fig. 8: Virtual spaces in YOLO Juliet

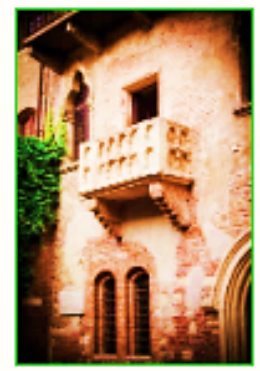

\section{Romeo has checked into the Grounds Below Juliet's Balcony.}

Source: (Shakespeare and Wright (b) 32). 
The oral nature of the theatrical medium is also preserved in the adaptations since the use of what Elleström calls "casual media" ("Adaptation and Intermediality") guarantees its spirit. The written texts in the digital media represented in $O M G$ series convey informal oral communication. The use of speech bubbles, symbols, cross-modal signs and all-caps (shouting) reinforce this. This passage from Macbeth \#killing it is a good example:

Fig. 9: Orality in texts

\section{Macbeth \\ THERE'S BLOOD ON UR FACE!!!}

Source: (Shakespeare and Carbone (a) 46).

Linda Hutcheon mentions that, besides media transposition, adaptation as a product may include genre and context shifts and may be seen as an intertext (Hutcheon; O'Flynn, 7-8). Erica Hateley also emphasizes that "adaptations of Shakespeare's works tend to retell the plot, or story, of one or more plays in a simplified format within short prose narratives" (27). One may say that, besides the educational purpose and the use of visual-iconic signs, "good reading material for children is said to be simple, clear" (Shuy 557) and concise. Simplicity is generally regarded as the use of accessible and explicit language, and the reduction of characterization and storytelling. In relation to verbal written text, the Shakespearean adaptations are characterized by simplification of the linguistic structure and "informalization". This may be due to the digital media portrayed (spontaneity, brevity and immediacy) and to the purpose linked to the chosen literary genre. In the passage from Macbeth \#killingit, one can clearly see the curtailment of lines in Macbeth's famous soliloquy (Macbeth 2.1.33-64) and the 
use of slangs, acronyms and emojis. It is also obvious the shift from poetic language to prose and the disappearance of the gloomy atmosphere produced by Shakespeare's imagery and language. The comic relief at the end of it may reflect the (mis)conception that young readers should only deal with moralizingly/light themes:

Fig. 10: Simplification and "colloquialization" in the written text BACK MACBETH

\section{I'm losing my_}

\section{floating in front of my_e $\bullet$ I reached out 2 grab it, but it}

\section{wasn't there IRL. WTF?! And now I have to finish the deed}

\section{b4 my wife kills me instead!}

Source: (Shakespeare and Carbone (a) 26).

In the context of Shakespeare's puns, one may say that there is not only a reduction in their use but also some loss in their ability to produce meaning. In the passage below, "At supper" has its potential meaning compromised by the use of the emoji: 
Fig. 11: Puns and emojis

\section{WHERE IS POLONIUS?}

Hamlet

\section{At supper.}

\section{Claudius}

Huh?

Hamlet

Well, "he's ${ }^{*}$ not eating, exactly.

Cuz he's in the ground. \#worms

Source: (Shakespeare and Carbone (b) 69-70)

By way of conclusion, it is possible to say that the $O M G$ Shakespeare series fulfils the aim of bringing Shakespeare's plays to the contemporary world of young English native readers. The series, as the publishing house states, does not intend to replace or disregard Shakespeare's plays. It seems to work as a teaser to the play, i.e., it stimulates young audiences, but at the same time, it prepares readers for the contact with the bard's plays. However, it is also feasible to add that these adaptations provide, to youth from different cultures, access to the Shakespearean world. It must be said that, in relation to non-native English-speaking audiences, the series acts like a mirror, revealing a multifaceted reflection of the British bard and his plays. Anyway, in both cases, it helps to establish a dialogue with a Shakespeare from a distant time and place.

It is not only the plot that is presented to digital generations, but mainly the bard's creative use of language. In this case, instead of neologisms, there is the use of visual iconic signs, symbols and 
acronyms. The bard's ability to portray contemporaneous culture ( $21^{\text {st }}$ century), just as he did in his time, and to please his audience is revealed in the adaptations. The passage below shows, in a funny way, the gap between digital natives and non-digital natives in society. Egeus's vexation refers not only to Hermia's behavior but also to his lack of ability to handle technological devices:

Fig. 12: Generation gap

Egeus

Good day, Theseus. Can you see this?

Theseus

Hey, pal. I can see this. Why the

Egeus

I don't know. My daughter, Hermia, downloaded this app onto my 䡒. I'm still learning!

Source: (Shakespeare and Wright (b) 4)

Shakespeare adapted other writers' stories to please his audiences and, at the same time, challenge them. His plays reflected his epoch and his culture but also went beyond such limits when dealing with linguistic innovation and manipulation and with universal themes and characters. This ability makes Shakespeare unfold, as professor Bruce Smith points out, "a different face to different cultures and different people at different times" (2016). The four adaptations are likely to create images of Shakespeare and of his plays that simultaneously reinforce the bard's role in the literary canon and 
reinvent his connection to the world. Some consider the use of emojis, for instance, a threat to literacy and to the understanding of Shakespeare. It could be said, however, that "far from being a devaluation of language, [emojis] are in fact an evolution of earlier pictographic and hieroglyphic language" (Alshenqeeti 58). Emojis, from this perspective, may be also seen as an adaptation to modern technologies since they provide emotional or physical cues for the digital context and can "traverse generational as well as crosscultural boundaries" (Alshenqeeti 60-61). Our analysis concludes, therefore, that the four rewritings are an effective creative format of achieving cross-culture communication. This is Shakespeare.

\section{References}

Alshenqeeti, Hamza. "Are Emojis Creating a New or Old Visual Language for New Generations? A Socio-semiotic Study". Advances in Language and Literary Studies, [s.1], 7.6 (2016): 56-69. Australian International Academic Center. Avaible to: http://www.journals.aiac.org.au/index.php/alls/article/view/2823. Acess: 10/02/2019.

Bloom, Harold. The Western Canon: The Books and School of the Ages. $1^{\text {st }}$ ed. New York/San Diego/London: Harcourt Brace \& Company, 1994.

Boston, Michelle. "Six reasons Shakespeare remains relevant 400 years after his death". USC News, [s.1], February 10, 2016. Avaible to: https://news.usc. edu/91717/six-reasons-shakespeare-remains-relevant-400-years-after-his-death/. Acess: 08/06/2019.

Elleström, Lars. "Iconicity as meaning miming meaning and meaning miming form." Signergy. 9. edited by C. Conradie et al. Amsterdam/Philadelphia: John Benjamins Publishing Company, 2010(a): 73 - 100. 
Elleström, Lars. "The Modalities of Media: A Model for Understanding Intermedial Relations." Media Borders, Multimodality and Intermediality. Hampshire/New York: Palgrave Macmillan, 2010(b): 11-50.

Elleström, Lars. "Spatiotemporal aspects of iconicity." Elleström, Lars; Fischer, Olga; Ljungberg, Christina. Iconic Investigations. Amsterdam/Philadelphia: John Benjamins Publishing Company, 2013(c): 95-117.

Elleström, Lars. “Adaptation and Intermediality.”. In: Leitch, Thomas (Ed). The Oxford Handbook of Adaptation Studies. New York: Oxford University Press, 2017(d): 509-526.

Elleström, Lars. "Identifying, Construing, and Bridging over Media Borders." Scripta Uniandrade. Curitiba, 16:3 (2018)(e): 15-30. Avaible to: https:// uniandrade.br/revistauniandrade/index.php/ScriptaUniandrade/article/ view/1162/926. Acess: 10/02/2019.

Emoji. Merriam-Webster.com, 2019. Avaible to: www.merriam-webster.com/ dictionary/emoji. Acess: 13/02/2019.

Garber, Marjorie. Shakespeare and modern culture. New York/Toronto: Pantheon Books, 2008: xiii-xxxv.

Hateley, Erica. Shakespeare in Children's literature: gender and capital culture. New York/Abingdon: Routledge, 2009.

Hutcheon, Linda; O'Flynn, Siobhan. A theory of adaptation. $2^{\text {nd }}$ ed. London and New York: Routledge, 2013.

Matei-Chesnoiu, Monica. "Space, Place, and Shifting Worlds in Shakespeare and Cervantes". Acta Iassyensia comparationes, special issue: 400 years with Shakespeare \& Cervantes. Universitatea Alexandru Ion Cuza, 2017. Avaible to: literaturacomparata.ro/aic/?page_id=677\&lang $=$ fr. Acess: 10/02/2019.

Oittinen, Riitta. "Audiences and influences: multisensory translations of picturebooks.” In: Davies, Maria Gonzáles; Oittinen, Riita.(Ed). Whose Story? Translating the Verbal and the Visual in Literature for Young Readers. New Castle: Cambridge Scholars Publishing, 2008: 3-18. 
OMG Shakespeare!. RHTeachersLibrarians.com. Random House Children's Books, 2015. Avaible to: https://images.randomhouse.com/promo_ image/9780553535396_3456.pdf. Acess: 10/02/2019.

Peirce, Charles Sanders. The Essential Peirce: Selected Philosophical Writings. v.2. Edited by the Peirce Edition Project. Bloomington/ Indianapolis: Indiana University Press, 1998.

Rajewisky, Irina O. "Border Talks: The Problematic Status of Media Borders in the Current Debate about Intermediality." In: Elleström, Lars. (Ed). Media Borders, Multimodality and Intermediality. Hampshire/New York: Palgrave Macmillan, 2010: 51-68.

Rippl, Gabriele. "Introduction”. In: Rippl, Gabriele. (Ed). Handbook of intermediality: literature - image - sound - music. Germany: De Gruyter, 2015: $1-31$.

Shakespeare, William; Carbone, Courtney. Macbeth \#killingit. New York: Penguin Random House, 2016.

Shakespeare, William; Carbone, Courtney. srsly Hamlet. New York: Penguin Random House, 2015.

Shakespeare, William; Wright, Brett. A midsummer night \#nofilter. New York: Penguin Random House, 2016.

Shakespeare, William; Wright, Brett. YOLO Juliet. New York: Penguin Random House, 2015.

Shuy, Roger W. "Four Misconceptions about Clarity and Simplicity." Language Arts, [s.1], 58.5 (1981): p. 557-561. Avaible to: www.jstor.org/stable/41961366. Acess: $10 / 02 / 2019$

Wolf, Werner. The Musicalization of Fiction: A Study in the Theory and History of Intermediality. Amsterdam/Atlanta: Rodopi, 1999. 
Word of the year 2015. OED Online, Oxford University Press, 2015. Avaible to: en.oxforddictionaries.com/word-of-the-year/word-of-the-year-2015. Acess: $14 / 02 / 2019$

Recebido em: 25/07/2019

Aceito em: 05/11/2019

Publicado em janeiro de 2020

Marcia Amaral Peixoto Martins. E-mail: martins@domain.com.br. ORCID: https://orcid.org/0000-0002-8663-1748

Ofélia da Conceição Machado Sagres. E-mail: ofeliasagres@gmail.com. ORCID: https://orcid.org/0000-0002-0468-5049 